\title{
Patient With Type 1 Distal Renal Tubular Acidosis Secondary to Sjogren's Syndrome Presented With Hypokalemic Paralysis
}

\author{
Mehmet Celik $^{\mathrm{a}, \mathrm{e}}$, Semra Ayturk ${ }^{\mathrm{a}}$, Onur Mert ${ }^{\mathrm{b}}$, Ahmet Kucukarda $^{\mathrm{b}}$, Ilhan Kurultak ${ }^{\mathrm{c}}$, Salim Donmez ${ }^{\mathrm{d}}$, \\ Sibel Guldiken ${ }^{\mathrm{a}}$, Armagan Tugrul ${ }^{\mathrm{a}}$
}

\begin{abstract}
Hypokalemia is described as serum potassium level below 3.5 $\mathrm{mEq} / \mathrm{L}$. The most common causes of hypokalemia are potassium loss from urinary tract, gastrointestinal system and loss through sweating, although decreased potassium intake and increased intracellular translocation may also cause hypokalemia. Severe hypokalemia may affect both cardiovascular and neuromuscular systems and can be life threatining. In the present report, we aimed to present a 47 -year-old female patient admitted with paralysis secondary to hypokalemia, who was later diagnosed with distal type 1 renal tubular asidosis (RTA) secondary to Sjogren's syndrome (SS).
\end{abstract}

Keywords: Hypokalemia; Type 1 distal renal tubular acidosis; Sjogren's syndrome

\section{Introduction}

Potassium is one of the important cations of the body and $98 \%$ of total body potassium is located in intracellular compartment. Intracellular and extracellular potassium ratio is a key factor in determining the cellular membrane potentials. For this reason, small changes in extracellular potassium level may cause significant deterioration in some organ systems $[1,2]$.

Hypokalemia is defined as serum potassium level below $3.5 \mathrm{mEq} / \mathrm{L}$ [3]. Potassium level of $2.5-3 \mathrm{mEq} / \mathrm{L}$ is moder-

Manuscript accepted for publication April 15, 2015

aDepartment of Internal Medicine, Division of Endocrinology and Metabolism, Trakya Medical School, University of Trakya, Edirne, Turkey

bDepartment of Internal Medicine, Trakya Medical School, University of Trakya, Edirne, Turkey

'Department of Internal Medicine, Division of Nephrology, Trakya Medical School, University of Trakya, Edirne, Turkey

${ }^{\mathrm{d} D e p a r t m e n t}$ of Internal Medicine, Division of Rheumatology, Trakya Medical School, University of Trakya, Edirne, Turkey

${ }^{\mathrm{e} C}$ Corresponding Author: Mehmet Celik, Department of Internal Medicine, Division of Endocrinology and Metabolism, Trakya University Medical Faculty, Edirne 22030, Turkey. Email: drmehmetcelik@hotmail.com

doi: http://dx.doi.org/10.14740/jmc2139w ate hypokalemia, while severe hypokalemia is defined as potassium level below $2.5 \mathrm{mEq} / \mathrm{L}[4,5]$. In hypokalemia, some important clinical signs may be seen in several organ systems such as cardiovascular and neuromuscular systems. Although moderate hypokalemia is usually asymptomatic, severe hypokalemia, which is usually rare, may be related to mortality and morbidity, causing skeletal muscle cramps, flask paralysis, hyporeflexia, rhabdomyolysis and important cardiac arrhytmias $[6,7]$. The most common causes of hypokalemia are potassium loss from urinary tract, gastrointestinal system and loss through sweating, although decreased potassium intake and increased intracellular translocation may also cause hypokalemia [8].

In this report, we present a case admitted with symptoms related to severe hypokalemia, in which type 1 distal renal tubular asidosis (RTA) secondary to Sjogren's syndrome (SS) was detected as causative etiology.

\section{Case Report}

A 47-year-old female patient was admitted to our outpatient clinic with muscle weakness and fatigue. Her past medical history revealed that she has been diagnosed with hypothyroidism for 14 years and has been using levothyroxin 100 $\mu \mathrm{g} /$ day. She has had severe intermittent fatigue and muscle weakness for the past 1 year and admitted to neurology outpatient clinic with these symptoms. Her biochemical examination had shown a serum potassium level of $1.9 \mathrm{mEq} / \mathrm{L} 1$ year ago (N: 3.5 - 5.5). Electromyoneurography (EMNG) had been performed and sensory-motor polyneuropathy had been detected. Patient had been referred to our outpatient clinic due to severe hypokalemia and subclinic hyperthyroidism. Hypothyroidism was detected and thyroid disease evaluation revealed the absance of autoimmune disease. Her hypothyroidism was thought to be secondary to a previous thyroiditis. Since present thyroxin replacement dose of the patient was high, levothyroxin dose was dropped to $75 \mu \mathrm{g} /$ day. On physical examination, BP was $120 / 80 \mathrm{~mm} \mathrm{Hg}$, pulse was $70 / \mathrm{min}$ and rhythmic. The power in all muscle groups was $4 / 5$. Sensation was normal but deep tendon reflexes were diminished. When laboratory examinations of the patient, which had been performed in the last 12 months, were evaluated, it was seen that all examinations revealed severe hypokalemia and there 
Table 1. Laboratory Values at Presentation

\begin{tabular}{|c|c|c|c|}
\hline & Unit & Value & Reference range \\
\hline \multicolumn{4}{|l|}{ Hemogram } \\
\hline $\mathrm{Hb}$ & $\mathrm{g} / \mathrm{dL}$ & 14.1 & $11.2-15$ \\
\hline WBC & $/ \mu \mathrm{L}$ & 6,550 & $4,000-10,000$ \\
\hline Platelet & $/ \mu \mathrm{L}$ & 237,000 & $150,000-450,000$ \\
\hline \multicolumn{4}{|l|}{ Biochemical parameters } \\
\hline Fasting glucose & $\mathrm{mg} / \mathrm{dL}$ & 92 & $70-105$ \\
\hline Urea & $\mathrm{mg} / \mathrm{dL}$ & 20 & $15-45$ \\
\hline Creatinine & $\mathrm{mg} / \mathrm{dL}$ & 0.8 & $0.57-1.11$ \\
\hline AST & $\mathrm{U} / \mathrm{L}$ & 18 & $0-34$ \\
\hline ALT & $\mathrm{U} / \mathrm{L}$ & 18 & $0-55$ \\
\hline Albumin & $\mathrm{g} / \mathrm{dL}$ & 3.9 & $3.2-5.2$ \\
\hline LDH & $\mathrm{IU} / \mathrm{L}$ & 110 & $100-190$ \\
\hline CK & $\mathrm{U} / \mathrm{L}$ & 265.4 & $0-170$ \\
\hline $\mathrm{Na}$ & $\mathrm{mmol} / \mathrm{L}$ & 139 & $136-145$ \\
\hline $\mathrm{K}$ & $\mathrm{mmol} / \mathrm{L}$ & 1.9 & $3.5-5.1$ \\
\hline $\mathrm{Cl}$ & $\mathrm{mmol} / \mathrm{L}$ & 119 & $99-107$ \\
\hline $\mathrm{Mg}$ & $\mathrm{mg} / \mathrm{dL}$ & 2.27 & $1.6-2.6$ \\
\hline Sedimentation rate & $\mathrm{mm} / \mathrm{h}$ & 14 & $0-20$ \\
\hline FT3 & $\mathrm{pg} / \mathrm{mL}$ & 3.58 & $1-4.2$ \\
\hline FT4 & $\mathrm{ng} / \mathrm{dL}$ & 1.39 & $0.8-1.8$ \\
\hline TSH & $\mathrm{mIU} / \mathrm{mL}$ & 0.06 & $0.5-4.78$ \\
\hline Anti-Tg & $\mathrm{IU} / \mathrm{mL}$ & 24.6 & $<115$ \\
\hline Anti-TPO & $\mathrm{IU} / \mathrm{mL}$ & 21.1 & $<34$ \\
\hline HBsAg & $\mathrm{s} / \mathrm{co}$ & - & - \\
\hline Anti-HCV & $\mathrm{s} / \mathrm{co}$ & - & - \\
\hline Anti-HIV & $\mathrm{s} / \mathrm{co}$ & - & - \\
\hline
\end{tabular}

were different results showing hypothyroidism, eutyhroidism and hyperthyroidism. For this reason, it was thought that there was no relationship between thyroid disease and hypokalemia. For this reason, we decided to make further evaluation for the etiology of hypokalemia. Her ECG was normal. In urine analysis, $\mathrm{pH}$ was $6.5(\mathrm{~N}: 4.5-8)$, potassium excretion in 24-h urine was $39.1 \mathrm{mEq} /$ day $(\mathrm{N}: 25$ - 125), and calcium excretion in 24-h urine was $224 \mathrm{mg} /$ day $(\mathrm{N}: 100-300)$. In arterial blood gas, $\mathrm{pH}$ was 7.28 (N: $7.35-7.45), \mathrm{PCO}_{2}$ was $24.4 \mathrm{~mm} \mathrm{Hg}\left(\mathrm{N}: 35\right.$ - 45), $\mathrm{SO}_{2}$ was $98.5 \%, \mathrm{HCO}_{3}$ was 11.4 $\mathrm{mEq} / \mathrm{L}\left(\mathrm{N}: 22\right.$ - 26), Na was $139 \mathrm{mmol} / \mathrm{L}(\mathrm{N}: 136-145), \mathrm{K}^{+}$ was $1.9 \mathrm{mmol} / \mathrm{L}(\mathrm{N}: 3.5$ - 5.1), chloride was $119 \mathrm{mmol} / \mathrm{L}(\mathrm{N}$ : 99 - 107), and anion gap was $8.6 \mathrm{mEq} / \mathrm{L}(\mathrm{N}: 8$ - 16). Serum lactate was negative. The other laboratory examination results are presented in Table 1. Renal ultrasonography showed calculi in the central part of the right kidney, which were 9 $\mathrm{mm}$ in diameter. Detailed history revealed that she has been complaining of dry eye and mouth for the last 4 months. The opthalmological examination was performed and Schirmer test revealed a positive result (both eyes $3 \mathrm{~mm} / 5 \mathrm{~min}$ ). Analy- sis of rheumatological markers showed RF: $10.7 \mathrm{IU} / \mathrm{mL}(\mathrm{N}: 0$ - 15), Hep-2 ANA on 1:100 dilution: granular pattern $(++++)$, anti-dsDNA: (-), anti-SSA: $(+++)$, anti-SSB: $(+)$, anti-Ro-52: $(+++)$. Lower lip salivary gland biopsy was performed but histopathological result could not be obtained due to insufficient material. We considered SS according to AmericanEuropean Consensus Group classification criteria and the patient was diagnosed with hypokalemia related to type 1 distal renal asidosis secondary to SS. Oral potassium tablet $2 \times 1$, hydroxychloroquine $200 \mathrm{mg} 2 \times 1$ and symptomatic treatment for dry eye were commenced. Her symptoms were improved and serum potassium levels turned to normal in 2 weeks under this theraphy. The appropriate follow-up scheme was planned and she was discharged.

\section{Discussion}

$\mathrm{SS}$ is a systemic, chronic and autoimmune disease characterized by lymphocytic infiltration of all exocrine glands, espe- 
cially salivary and lacrimal glands [9]. It is called as primary $\mathrm{SS}$ if there is no underlying pathology. In secondary SS, there is an underlying pathology such as systemic lupus erythematosus and rheumatoid arthritis. Fifty percent of the cases are primary SS. SS prevalance of the population is approximately $4 \%$. It is nine times more common in females. Although it is generally seen at around 40 - 50 years of age, it can be seen in all ages [10].

This is basically an autoimmune exocrinopathy involving many body systems and organs, although it is most commonly associated with dry eye and mouth. American-European Consensus Group proposed the diagnostic criteria which includes clinical information and laboratory examination values [11]. Our patient fulfilled the defined criteria for primary SS (dry eye and month longer than 3 months, positive Schirmer test, presence of autoantibodies SS-A and SS-B) when evaluated according to these diagnostic criteria.

Renal disease is seen in approximately $10 \%$ of all SS patients. It mainly (33\%) occurs in the form of RTA and $90 \%$ of them are type 1 distal RTA. Although how SS causes type 1 distal RTA is exactly not known, it was suggested that absent or decreased activity of H+-ATPase of intercalated cells located in collecting tubules of distal nephrone may play role in the pathogenesis [12]. Despite decreased urinary acidification and hyperchloremic metabolic acidosis, distal RTA is characterized by urinary $\mathrm{pH}$ above 5.5 . Distal RTA can be primary (either idiopathic or inherited) or secondary. Secondary distal RTA occurs with calcium metabolism disorders, genetical and autoimmune diseases [13]. In our case, presence of hypokalemia, renal calculi and hyperchloremic metabolic acidosis, urinary $\mathrm{pH}$ of 6.5 and absence of a positive familial history were all suggestive for type 1 distal RTA secondary to primary SS. Distal RTA may cause some renal disorders such as nephrocalcinosis, urolithiasis and chronic interstitial nephritis.

The most common electrolyte disturbance in distal RTA is hypokalemia. Signs and symptoms are related to the severity of hypokalemia. As also seen in the present case, hypokalemia may cause periodic paralysis. Hypokalemic periodic paralysis may be primary or secondary to thyrotoxicosis, primary hyperaldosteronism, distal RTA, gastrointestinal disorders and barium intoxication. Hypokalemic periodic paralysis secondary to RTA is rarely seen $[14,15]$. In addition to the treatment of the pathology causing distal $\mathrm{RTA}, \mathrm{HCO}_{3}$ and $\mathrm{K}^{+}$replacements are also necessary. We also prescribed hydroxychloroquine to decrease symptoms related to SS, artificial tear drop, bicarbonate and potassium preparations for distal RTA.

In conclusion, in patients presented with periodic paralysis secondary to hypokalemia, investigation of underlying causes is essential and distal RTA secondary to SS should be considered.

\section{Competing Interests}

The authors declare that they have no competing interests.

\section{Financial Support}

Contributors, either individually or collectively, have no financial support, including pharmaceutical company support, authorship or promotion of the contribution.

\section{References}

1. Clausen T, Everts ME. Regulation of the Na,K-pump in skeletal muscle. Kidney Int. 1989;35(1):1-13.

2. Doucet A. Function and control of Na-K-ATPase in single nephron segments of the mammalian kidney. Kidney Int. 1988;34(6):749-760.

3. Singer GG, Brenner BM. Fluid and electrolyte disturbances. In: Braunwald E, Fauci AS, Kasper DL, et al, eds. Harrison's principles of internal medicine. 15th ed. New York: Mc Graw Hill; 2001. p. 279-283.

4. Halperin ML, Kamel KS. Potassium. Lancet. 1998;352(9122):135-140.

5. Mandal AK. Hypokalemia and hyperkalemia. Med Clin North Am. 1997;81(3):611-639.

6. Comi G, Testa D, Cornelio F, Comola M, Canal N. Potassium depletion myopathy: a clinical and morphological study of six cases. Muscle Nerve. 1985;8(1):17-21.

7. Rose BD, Post TW. Hypokalemia. In: Rose BD, Post TW, eds. Clinical Physiology of Acid-Base and Electrolyte Disorders, 5th ed. New York: McGraw-Hill; 2001. p.836856.

8. Mount DB, Zandi-Nejad K. Disorders of potassium balance. In: Brenner BM, eds. Brenner and Rector's The Kidney. Philadelphia: WB Saunders Co; 2008. p.547-587.

9. Feltsan T, Stanko P, Mracna J. Sjogren s syndrome in present. Bratisl Lek Listy. 2012;113(8):514-516.

10. Fox PC. Autoimmune disease and Sjogren's syndrome. Ann NY Acad Sci. 2007;1098:S15-21.

11. Vitali C, Bombardieri S, Jonsson R, Moutsopoulos HM, Alexander EL, Carsons SE, Daniels TE, et al. Classification criteria for Sjogren's syndrome: a revised version of the European criteria proposed by the American-European Consensus Group. Ann Rheum Dis. 2002;61(6):554558.

12. Cohen EP, Bastani B, Cohen MR, Kolner S, Hemken P, Gluck SL. Absence of $\mathrm{H}(+)$-ATPase in cortical collecting tubules of a patient with Sjogren's syndrome and distal renal tubular acidosis. J Am Soc Nephrol. 1992;3(2):264271.

13. Jurgen Floege, Richard J Johnson, John Feehally. Comprehensive clinical nephrology, 4th ed. Section 3. p. 158159.

14. Antes LM, Kujubu DA, Fernandez PC. Hypokalemia and the pathology of ion transport molecules. Semin Nephrol. 1998;18(1):31-45.

15. Gutmann L. Periodic paralyses. Neurol Clin. 2000;18(1):195-202. 